outbreak of war, in 1914, went to France with the B.E.F. as officer in charge of maps at G.H.Q. In this post, which he held throughout the War, he was responsible for directing and controlling a great variety of survey developments, including the mapping of the trench lines, German as well as British; sound-ranging and flash-spotting (for the location of enemy batteries) ; and, last but far from least, the 'Artillery survey' procedure, which made possible the sudden accurate bombardments of 1918 by massed artillery - a development which, from the battle of Cambrai onwards, contributed so much to the Allied victory.

For his services in the First World War Jack was awarded the C.M.G. and the D.S.O. and was several times mentioned in dispatches. The Royal Geographical Society, which in 1916 had given him its Gill Memorial Award for his work in Africa, awarded him its Founder's Medal for his geographical work on the Western Front. In 1920 he became head of the Geographical Section, and two years later succeeded Sir Charles Close as director-general of the Ordnance Survey. In 1924 he was promoted to the rank of brigadier, and in 1928 was made a C.B.

Jack retired from the Service in 1930 , but this 'official' retirement was only the beginning of another career of unpaid service to many charitable and other causes, scarcely less distinguished than the one he had just completed, and which lasted for twenty years more. The kindliest and most modest of men, Brigadier Jack has left a record which any man might envy; and a memory which all his many friends will cherish.

M. N. MACLEOD

\section{Prof. E. Baldi}

Prof. Edgardo Baldi died on August 10 at the age of fifty-two very much regretted by all his friends and colleagues. He was director of the Istituto Italiano di Idrobiologia at Pallanza on the Lago Maggiore, a research institute founded in 1939 which has become one of the world's leading limnological laboratories.

Baldi's research career began with work on insect neurophysiology which has left important traces in the literature. He soon turned, however, to hydrobiology, beginning with systematic work, especially on diaptomid copepods. He made a study of the distribution of the various races of Eudiaptomus vulgaris in Italian lakes. One of his favourite fields of research was the biology of alpine lakes, the chief object of which was to define the communities and discover their degree of temporal constancy. Rivers were also studied, the main thread of the research being the seasonal variation and survival in rivers of plankton derived from lakes.

In the last period of his life, Baldi's particular interest was in the biometrical study of form differences between planktonic Crustacea of certain species belonging to populations of varying density living in different parts of a lake. General accounts of this important part of his work are to be found in Experientia, 2, 476 (1946) and Vierteljahrschrift Naturf. Ges. Zürich, 95, 89 (1950), while details are in the Memorie Ist. Ital. Idrobiol. His was always the spirit of pure scientific research for its own sake. To British and other foreign biologists who had the pleasure of visiting or working in his Institute, Baldi always extended a most generous welcome.

H. Munko Fox

\section{Dr. G. A. Shakespear}

Dr. Gillbert Arden Shakespear, who died as a result of a road accident within a few days of his seventy-eighth birthday, was a prominent member of the University of Birmingham for more than half a century. Educated at Wyggeston School, Leicester, and Mason College, Birmingham, he was one of J. J. Thomson's research students at Cambridge before returning to Birmingham as lecturer under Poynting. $\mathrm{He}$ was acting professor during 1914-19 and, though he retired in 1938, he continued active research work in the Department of Physics.

Dr. Shakespear was distinguished for his ingenuity and skill in making precise measurements by simple methods. Much of his early work was inspired by Poynting, whom he greatly admired, and was concerned with thermal radiation. His most important contribution to science, however, arose from a practical need and was made with characteristic speed and perfection. During the First World War his attention was directed to the need for measuring the purity of hydrogen in connexion with airships and observation balloons; he quickly produced his 'katharometer', a sensitive and robust apparatus for gas analysis by thermal conductivity, and then applied it in many different directions, the principal one at that time being the permeability of rubberized fabrics.

Although the instrument has now been extensively used in measuring mixtures of many gases and in all kinds of applications, it still remains in the essentially simple form which Shakespear originally devised. The katharometer, in the hands of many workers, has been the means of making substantial contributions to many branches of science-physics, biology, physiology, medicine and chemical engineering. It is ideally suitable for measuring diffusion and thermal diffusion : it is used for measuring the respiration of plants and animals, for the control of anæsthetic gas mixtures, for the analysis of flue gases and the exhaust gases from internal combustion engines, and in ammonia plants. An indication of Shakespear's ingenuity and breadth of interest is given by the fact that with only a slight modification he was able to convert the katharometer into a very sensitive extensometer.

Shakespear was always most generous in freely giving his ideas to others. He delighted in having problems brought to him and in assisting in their solution. For this he wanted no recognition or reward; his pleasure lay in sharing in the enthusiasm for any subject and in sowing the seed of progress. His influence has thus been much greater than can be measured by the volume of his published work.

In his teaching, Shakespear was remarkable for his originality and freshness of approach on the experimental side of his subject. A student's measurement of the acceleration due to gravity in the elementary laboratory was to him a matter of importance and excitement, in which the result really mattered.

Shakespear was a man of extraordinary activity, both mental and physical, and an uncommonly keen observer of every thing that lives and moves, as well as of the inanim ate things. His wife, the late Dame Ethel Shakespear, was a geologist and a notable figure in the pub ic life of the Midlands. Their farm, garden and laboratory at Caldwell Hall, near Bromsgrove, formed an ideal centre for a rare breadth of interests. 